\title{
Sistem Informasi Pendaftaran Pasien Rawat Jalan Menggunakan PHP Dan MySQL Pada Puskesmas Dompu Kota
}

\author{
Fadlun Mudin ${ }^{1}$, Dwinita Arwidiyarti², Emi Suryadi ${ }^{3}$ \\ STMIK Mataram ${ }^{1,2,3}$ \\ emisuryadi@gmail.com
}

\begin{abstract}
Abstrak - Puskesmas dompu kota adalah salah satu Puskesmas yang ada di Kabupaten Dompu. Puskesmas ini memiliki beberapa poli yaitu, poli gigi, poli umum, poli anak, poli UGD, poli THT dan poli kandungan. Prosedur pendaftaran pasien baru yang berlaku adalah calon pasien melakukan pendaftaran secara manual di bagian CO (Central Opname) dengan menyebutkan data dirinya yang akan dicatat oleh petugas $\mathrm{CO}$ pada form pendaftaran dan kemudian dibuatkan kartu pasien. Buku daftar kunjungan pasien diberi nomor antrian bertujuan untuk mengetahui urutan poli yang dituju untuk berobat. Kondisi pendaftaran pasien ini menjadi tidak efektif karena hanya mengandalkan catatan pada form dan buku daftar kunjungan yang memungkinkan akan terjadi hilang, terselip dan tercecer. Sistem informasi yang dibuat saat ini dapat mengolah data pasien yang mencakup penginputan, penyimpanan, perubahan, penghapusan serta pencetakan sehingga pengolahan data pasien yang semula manual menjadi terkomputerisasi yang berdampak pada proses lebih cepat dan data dapat tersimpan dengan lebih aman.
\end{abstract}

Kata Kunci : Puskesmas dompu kota, pendaftaran pasien, kartu pasien, Sistem Informasi

\section{Latar Belakang}

Perkembangan teknologi khususnya teknologi informasi telah merambah ke segala bidang termasuk bidang pelayanan kesehatan. Puskesmas Dompu Kota adalah salah satu Puskesmas yang ada di Kabupaten Dompu. Saat ini pengolahan data pendaftaran pasien rawat jalan di Puskesmas Dompu Kota masih dilakukan secara manual. Prosedur pendaftaran pasien baru yang berlaku adalah calon pasien melakukan pendaftaran di bagian CO (Central Opname) dengan menyebutkan data dirinya yang akan di catat oleh petugas $\mathrm{CO}$ pada form pendaftaran dan kemudian dibuatkan kartu pasien. Sedangkan pasien lama prosedur pendaftarannya adalah pasien menyerahkan kartu pasien kepada petugas CO (Central Opname) kemudian petugas mencatat data kunjungan ke dalam buku daftar kunjungan pasien lalu diberi nomor antrian berdasarkan poli yang dituju. Pendaftaran pasien menjadi tidak praktis, karena data pasien hanya mengandalkan catatan pada form dan buku daftar kunjungan yang masih memungkinkan hilang, terselip, tercecer, sulit dalam pencarian dan penyajian laporan.

Mengatasi problem yang ada, puskesmas dompu kota membutuhkan sebuah sistem informasi yang dapat mengolah data pasien yang mencakup penginputan, penyimpanan, perubahan, penghapusan serta pencetakan sehingga pengolahan data pasien yang semula manual menjadi terkomputerisasi. Sistem informasi pendaftaran pasien rawat jalan di Puskesmas Dompu Kota menjadi lebih cepat, data dapat tersimpan dengan lebih aman, memudahkan dalam pencarian dan penyajian informasi serta menekan biaya dalam penggunaan kertas.

\section{Kajian Pustaka}

a. Sistem Informasi

Naskah publikasi milik Oliya dkk. dengan judul Perancangan Sistem Informasi Berbasis Website di Sekolah Vokasi Universitas Muhammadiyah Surakarta (Menggunakan Microsoft Dreamwaver 8 dan PhpMyAdmin). Mengatakan pada jurnalnya bahwa, sistem adalah sekumpulan elemenelemen didalam suatu data yang dapat memberikan suatu hasil atau keluaran yang diharapkan dari sistem tersebut, yang mana sistem ini terdiri dari elemen yang saling berurutan dan saling berkaitan. Elemen-elemen yang terkandung dalam suatu sistem dapat dijabarkan pada Gambar 1 di bawah ini.

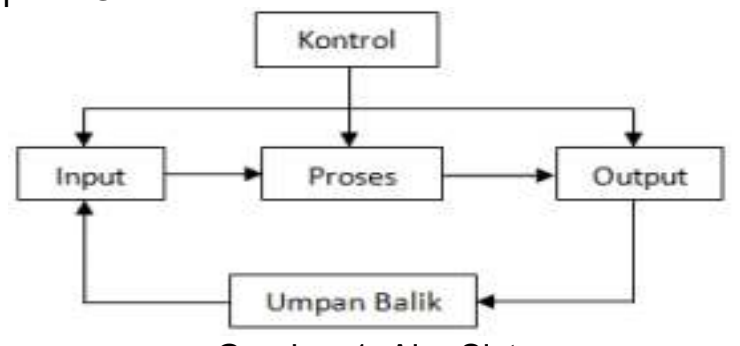

Gambar 1. Alur Sistem

Sistem informasi adalah suatu sistem yang dibuat manusia yang terdiri dari komponen-komponen dalam organisasi untuk mencapai suatu tujuan yaitu menyajian informasi. 


\section{b. Pendaftaran Pasien Rawat Jalan}

Menurut surat keputusan menteri kesehatan RI no.269/MENKES/PER/III/2008 tentang rekam medis, pasien adalah setiap orang yang melakukan konsultasi masalah kesehatannya untuk memperoleh pelayanan kesehatan yang diperlukan baik secara langsung maupun tidak langsung kepada dokter. Sedangkan untuk pendaftaran pasien rawat jalan menurut surat Keputusan Menteri Kesehatan RI no. 560/MENKES/ SK/IV/2003 tentang tarif perjanjian puskesmas bahwa rawat jalan adalah pelayanan pasien untuk observasi, diagnosis, pengobatan, rehabilitasi medic dan pelayanan kesehatan lainnya tanpa menginap di puskesmas.

\section{c. Program Pendukung}

Perangkat kebutuhan yang digunakan untuk membuat sistem ini adalah.

1) Web Browser

Web browser adalah program atau software yang dirancang untuk mencari dan menampilkan dokumen web dalam format HTML. Dengan browser, para pengguna komputer dapat mencari atau menelusuri (browser) serta melihat dari isi dokumen web dan berpindah dari sebuah tempat (halaman) ke tempat lain di web (Husda dkk, 2016:129).

2) $\mathrm{PHP}$

PHP (Personal Home Page) adalah salah satu bahasa pemograman skrip yang dirancang untuk membangun aplikasi web. Program yang ditulis dengan PHP akan di-parsing di dalam web server oleh interpreter PHP dan diterjemahkan ke dalam dokumen HTML, yang selanjutnya akan ditampilkan kembali ke web browser. Pemrosesan program PHP dilakukan di lingkungan web server, PHP dikatakan sebagai bahasa sisi server (server-side).

3) MySQL

MySQL adalah salah satu aplikasi DBMS yang sudah sangat banyak digunakan oleh para programmer aplikasi web. DBMS yang dimasukkan adalah PostgreSQL (freeware), SQLserver, MS Access dari Microsoft, DB2 dari IBM, Oracle dan Oracle Crop, Dbase, FoxPro dan sebagainya.

4) Notepad++

Notepad++ adalah sebuah penyunting teks dan penyunting kode sumber yang berjalan di sistem operasi Windows. Notepad++ menggunakan komponen Scintilla untuk dapat menampilkan dan penyuntingan teks dan berkas kode sumber berbagai bahasa pemrograman.

5) CSS

Cascading Style Sheet (CSS) adalah bahasa pemograman yang digunakan untuk membuat halaman web yang dinamis. CSS sudah didukung oleh hampir semua web browser karena CSS telah distandarkan oleh Word Wide Web Consortium (W3C) (Hidayatullah P dan K.K Jauhari, 2014:53).

\section{Perancangan Sistem}

Perancangan sistem merupakan bagian dari metodologi pengembangan suatu perangkat lunak yang dilakukan setelah melalui tahapan analisis. Perancangan bertujuan untuk memberikan gambaran secara terperinci yang akan dibangun sebelum dilakukan pengkodean kedalam suatu bahasa pemrograman. Dalam perancangan sistem ini menggunakan UML (Unified Modelling Language) sebagai rancangan dari sebuah model sistem yang akan dibangun.

\section{a. Use Case Diagram}

Use case diagram ini merupakan gambaran yang ada pada sistem pelayanan pendaftaran pasien rawat jalan. Berikut use case yang ada pada sistem pelayanan pendaftaran dapat dilihat pada Gambar 2 di bawah ini.

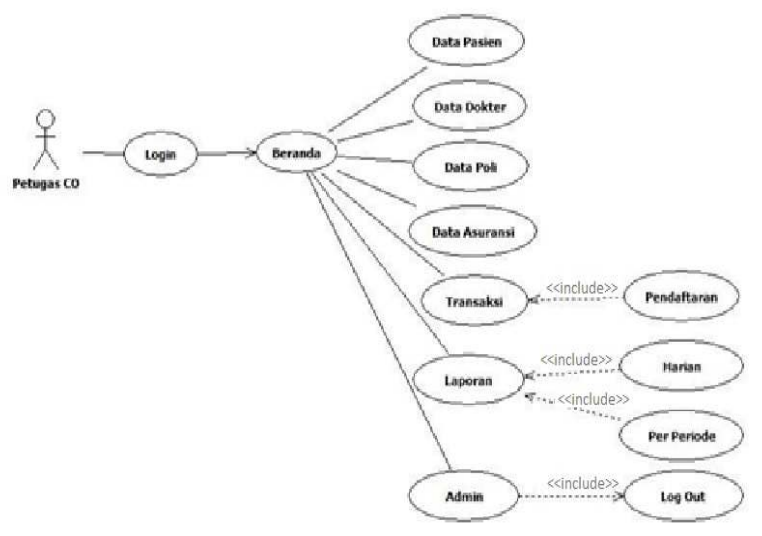

Gambar 2. Use Case Diagram

\section{b. Sistem Alternatif}

Untuk mengatasi permasalahan yang dihadapi dalam pelayanan pendaftaran pasien rawat jalan pada Puskesmas Dompu Kota dikembangkan sistem baru yang akan memudahkan petugas untuk mendata dan mengelola data pasien. Sistem baru tersebut dapat dijelaskan pada Gambar 3 di bawah ini : 


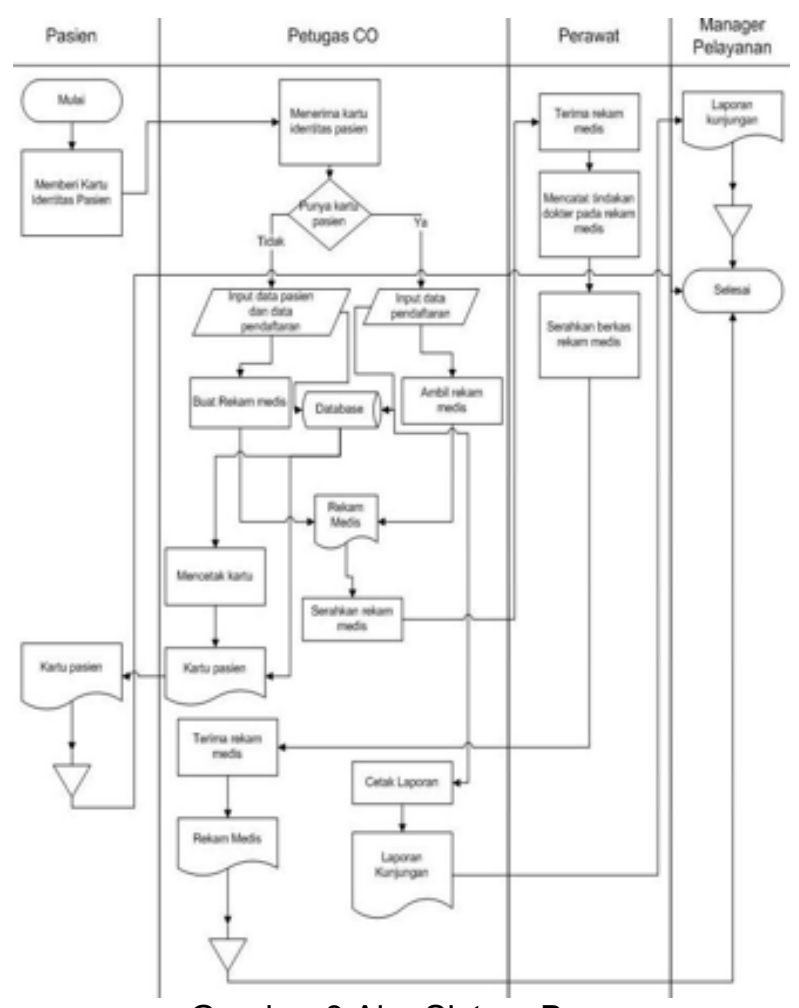

Gambar 3 Alur Sistem Baru

c. Entitiy Relationship Diagram (ERD)

Menurut salah satu para ahli, Brady dan Loonam (2010), Entity Relationship diagram (ERD) merupakan teknik yang digunakan untuk memodelkan kebutuhan data dari suatu organisasi, biasanya oleh System Analys dalam tahap analisis persyaratan proyek pengembangan system. Hubungan yang terjadi dalam tabel-tabel yang disusun dalam sebuah ERD yang terlihat pada Gambar 4 di bawah ini.

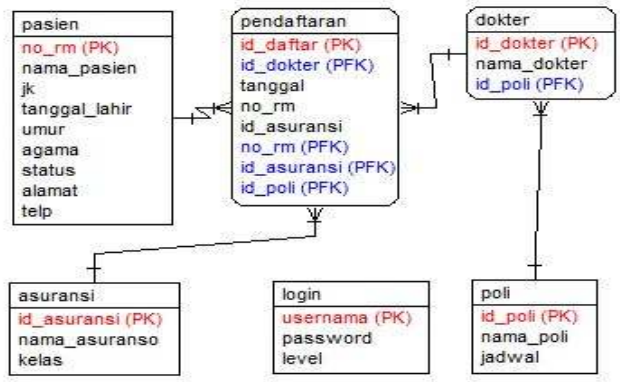

Gambar 4 Entity Relationship Diagram

\section{d. Arsitektur Program (Struktur Program)}

Arsitektur program yang dirancang sebagai gambaran singkat dari sistem informasi. Struktur program yang ada dapat dilihat pada Gambar $5 \mathrm{di}$ bawah ini

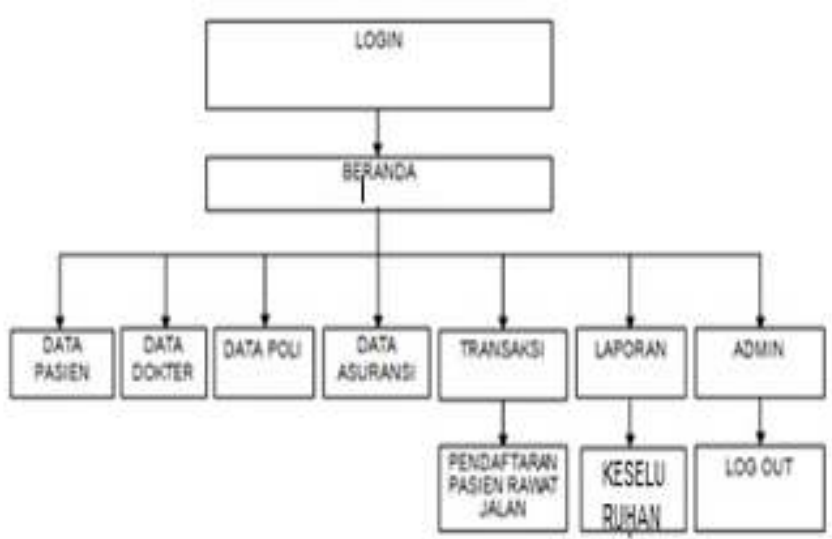

Gambar 5. Arsitektur Program

4. Implementasi Sistem dan Hasil

Hasil pengujian yang dilakukan pada sistem pendaftaran pasien rawat jalan ini telah membuktikan kemampuannya untuk membantu puskesmas dompu kota yang awalnya manual dalam penginputan data pasien menjadi terkomputerisasi.

\section{a. Halaman Data Pasien}

Pada halaman data pasien akan ditampilkan data-data pasien yang sudah tersimpan di database. Data pasien ditampilkan dalam bentuk tabel seperti yang ada pada Gambar 6 sebagai berikut.

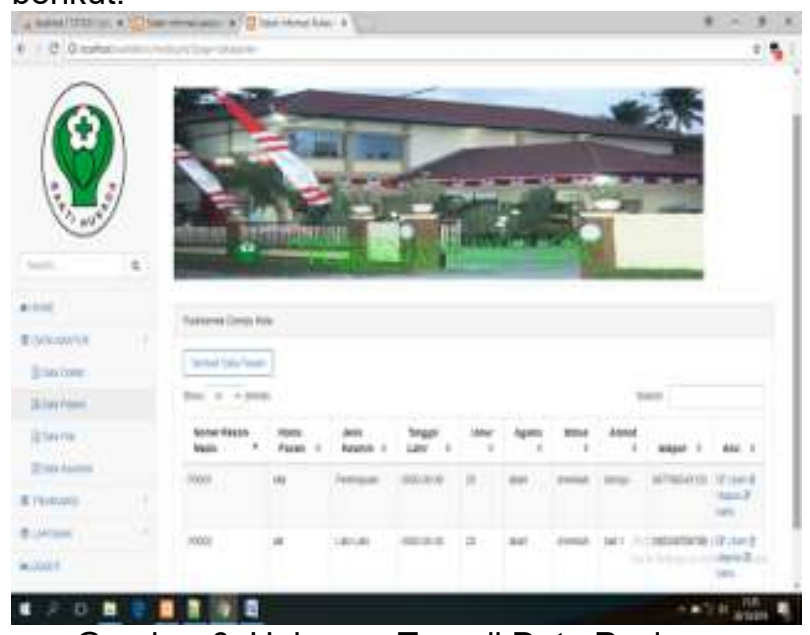

Gambar 6. Halaman Tampil Data Pasien

\section{b. Halaman Input Data Pasien}

Input data pasien berupa form isian yang terdiri dari beberapa textfield (kotak isian) yang digunakan untuk memasukkan dan menambah data pasien. Setelah melengkapi form isian lalu mengklik tombol simpan, maka data- data yang telah diinputkan akan diproses dan akan masuk secara otomatis kedalam database. Untuk lebih jelas dapat dilihat pada Gambar 7 di bawah ini. 


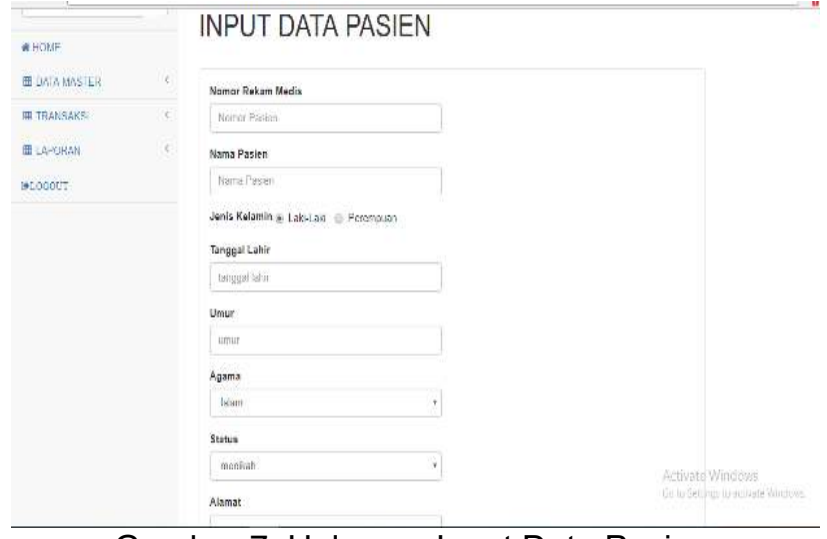

Gambar 7. Halaman Input Data Pasien

\section{c. Halaman Ubah data Pasien}

Halaman ini berupa form isian yang terdiri dari beberapa textfield (kotak isian) yang digunakan untuk merubah data pasien yang sudah tersimpan pada database. Halaman ubahnya dapat dilihat pada Gambar 8 berikut.

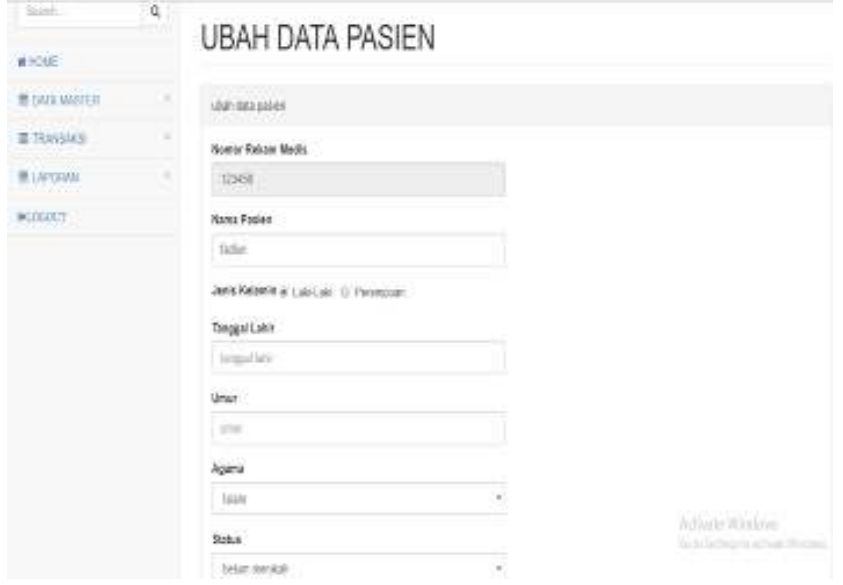

Gambar 8. Halaman Ubah Data Pasien

\section{d. Halaman Data dokter}

Data dokter yang ditampilkan merupakan data yang telah diinputkan yang terdiri dari beberapa field yaitu ID dokter, nama dokter dan spesialis. Data dokter dapat dilihat Pada Gambar 9 berikut ini.

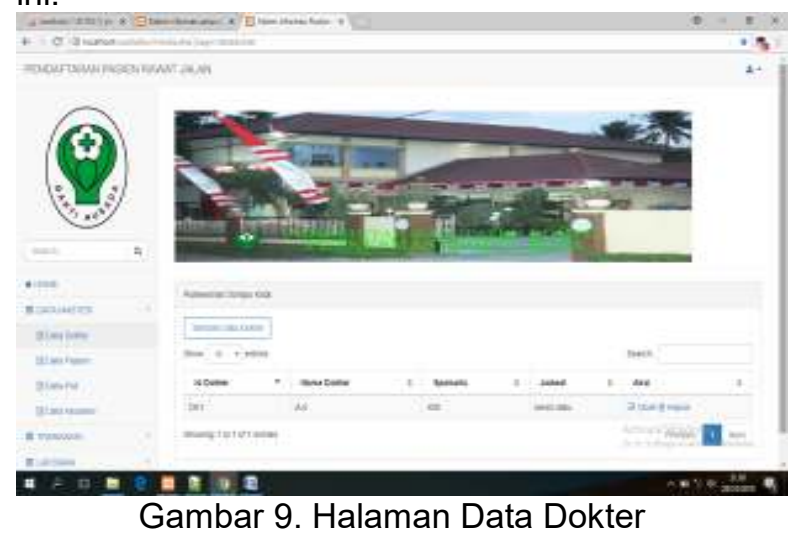

\section{e. Halaman Data Poli}

Data poli yang ditampilkan merupakan data yang telah diinputkan yang terdiri dari beberapa field yaitu ID poli, nama poli dan jadwal. Halaman data poli seperti yang terlihat pada Gambar 10 di bawah ini.

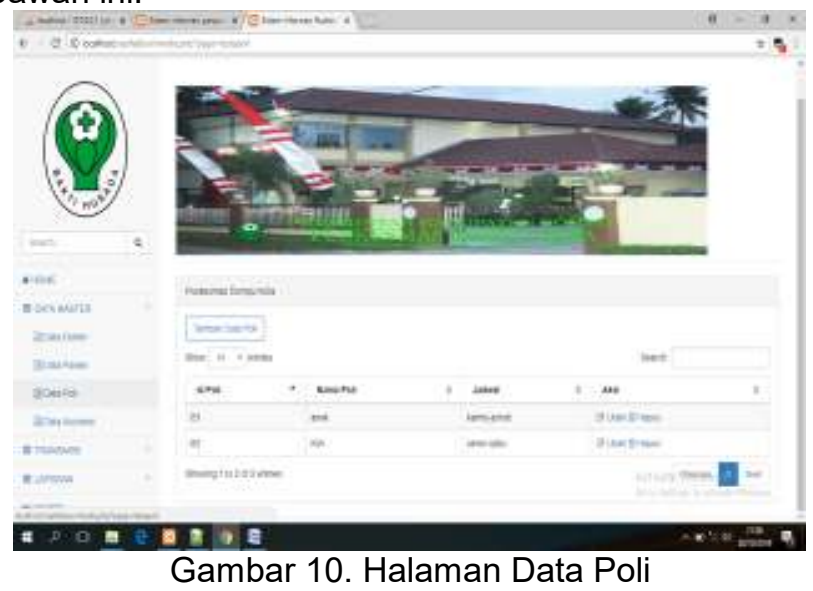

f. Halaman Data Asuransi

Pada halaman data asuransi akan ditampilkan data-data asuransi yang sudah tersimpan di database. Keterangannya dapat dilihat pada Gambar 11 berikut ini.

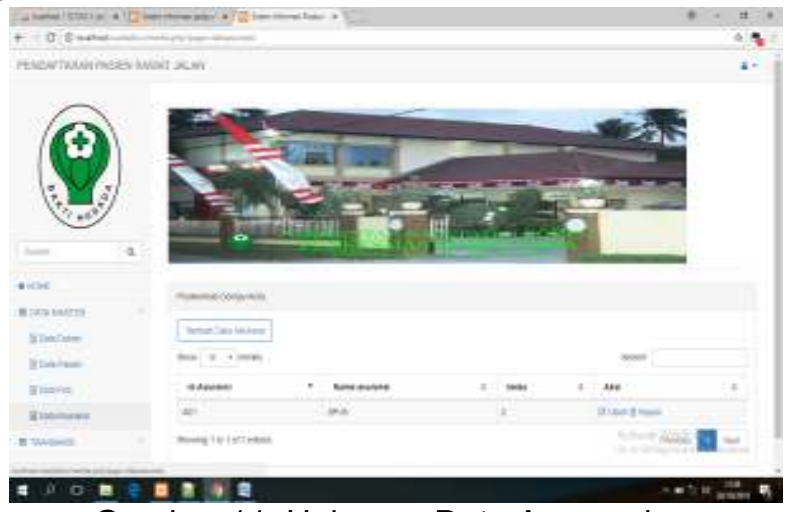

Gambar 11. Halaman Data Asuransi

\section{g. Halaman Laporan}

Halaman laporan harian ditampilkan data-data hasil transaksi pendaftaran pasien secara keseluruhan dalam bentuk tabel. Tombol cetak pada halaman mengacu pada pencetakan laporan pendaftaran secara keseluruhan, sedangkan tombol laporan harian mengacu pada laporan harian yang berlaku pada hari terkini. Keterangannya dapat diihat pada Gambar 12 di bawah ini. 


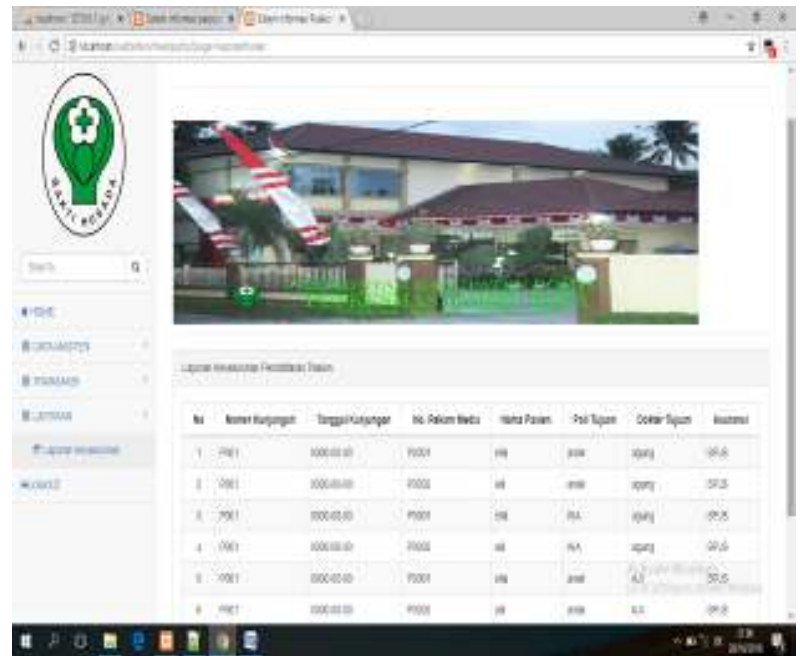

Gambar 12. Halaman Laporan

\section{Kesimpulan}

Sistem Informasi Pendaftaran Pasien Rawat Jalan Menggunakan PHP dan MySQL dengan menerapkan metodelogi pengembangan perangkat lunak waterfall yang telah dilakukan sampai tahap testing. Perancangan sistem ini dilakukan dengan Flowchart System dan Diagram UML yang terdiri dari Use Case Diagram dan Activity Diagram. Sistem Informasi hanya dapat digunakan oleh petugas $\mathrm{CO}$ untuk menginputkan data pasien dan sebagainya. Output tercetak yang dihasilkan berupa kartu pasien, laporan harian dan laporan per periode. Dengan adanya sistem informasi Pendaftaran rawat jalan akan dapat membantu mempermudah dalam pengolahan data pasien pada Puskesmas dompu kota.

\section{Pustaka}

Dharwiyanti, S, dan Romi S, W. 2003. Pengantar Unified Modeling Language (UML).

Fauziah. 2014. Konsep Dasar Perancanngan Web. Jakarta: Penerbit Mitra Wacana Media.

Febriyanti, H dan Eri Zuliarso. 2012. Rancang Bangun Sistem Perpustakaan untuk Jurnal Elektronik. Jurnal Teknologi Informasi DINAMIK. Volume 17. No.2: 124-132.

Hartono, J. 1989. Analisis \& Desain. Yogyakarta: ANDI

Naskah publikasi Oliya dkk. dengan judul Perancangan Sistem Informasi Berbasis Website di Sekolah Vokasi Universitas Muhammadiyah Surakarta (Menggunakan Microsoft Dreamwaver 8 dan PhpMyAdmin).

Tim EMS. 2014. Teori dan Praktik PHP - MySQL untuk Pemula. Jakarta: PT Elex Media Komputindo.
Turban,dkk. 2006. Pengntar Teknologi Informasi Edisi 3. Jakarta: Penerbit Salemba Infotek. 